ISBN 978-81-933894-1-6 International Conference on Arts, Social Sciences, History and Interdisciplinary Studies

(ASSHIS-2017)

Kyoto (Japan) April 20-21, 2017

\title{
Investigation of Language Learning Style Preferences of Thai Airline Business Students
}

\author{
Nantiya Unnahasuttiyanon \\ Aviation Personnel Development Institute \\ KasemBundit University, Bangkok, Thailand
}

\begin{abstract}
English language has been implemented in classrooms in Thailand for several decades and various approaches of teaching have been employed to promote learning. However, Thai students do not seem to be successful with their learning. The present study aimed to investigate the language learning style preferences of Thai students majoring in airline business, along with the extent of teachers' awareness of them, thus giving insights and making suggestions for better and more effective class activities to promote the students' achievement in English language learning. A 13-item questionnaire adapted from Brindley (1984) was utilized to collect data for the study. The questionnaire was administered to 563 students majoring in airline business at a private university in Thailand and 8 teachers teaching these students in the same institution. The data collected was analyzed using the percentages to achieve the main goal of the study. A t-test was also conducted to observe if there was a correlation between teachers' and students' responses. The results showed the learning preferences of students in different areas and it can be observed that students' preferences do indeed correlate with those of teachers in many cases. However, the results obtained here call for a step forward towards a closer co-operation between teachers and students in some instances in designing syllabuses, doing weekly course planning, and classroom management.
\end{abstract}

Keywords: English language, language learning style preferences, airline business students

\section{Introduction}

The aviation business in the ASEAN region is likely to expand significantly when the ASEAN Economic Community (AEC) goes into full effect. The coming of AEC leads to the opening of several new airlines and aviation routes. More tourist arrivals within the region have been seen, together with the growth in the aviation business. As a result, airline staff is in great demand, and many airlines try to recruit more employees. Many universities in Thailand have realized this potential and have recently offered the Bachelor of Arts in Airline Business to provide courses that focus on fundamental airline management and operational skills to prepare students for their future career. However, to be able to perform effectively as airline industry professionals, the students need not only those knowledge and working skills but also the English language skills.

However, the English proficiency level of Thai students is still far from satisfactory. Test and Score Data Summary (2015) presents the average level of Thai students' English skills measured by TOEFL iBT as 77 out of 120 points. When compared to other ASEAN countries, except Brunei Darussalam, Thailand is only ahead of Cambodia and Laos. Thailand lags far behind major ASEAN countries like Singapore, Malaysia, Philippines, and Indonesia. It could be indicated that Thai students are required to improve their English skills; otherwise, many might lose their jobs or find it difficult to work in ASEAN Economic Community (AEC). Especially airline business students, they need to be not only qualified at general English (GE) but also capable of interpreting the specialist contents.

English language has been implemented in classrooms in Thailand for several decades and various approaches of teaching have been employed to promote learning. However, Thai students do not seem to be successful with their learning. One important explanation for this failure is the mismatch between teaching and learning approaches (Allwright \& Bailey, 1991). If teachers learn more about their students and be aware of their learning style preferences, they are in a better position to anticipate such mismatches and devise more effective strategies for bridging the gaps between teaching and learning (Littlewood, Liu, \& Yu, 1996). Therefore, the present research aimed to study and determine the language learning style preferences of Thai students majoring 
in airline business and to investigate the ideas of the teachers teaching these students regarding their students' needs and preferences, thus giving insights and making suggestions for better and more effective class activities to promote the students' achievement in English language learning.

\section{Literature Review}

\subsection{Definitions of Learning Styles}

Many researches on learning style have been developed during the past three decades. Learning style was defined by several researchers. Dunn (1990) defined learning style as "the way in which individuals begin to concentrate on, process, internalize and retain new and difficult information". Davidson (1990) proposes that learning style is "an individual's characteristic mode of gaining, processing, and storing information". He stated that students preferred to use the style as it was familiar and made it easier to learn. De Bello (1990) suggests that learning style refers to "the way people absorb, process and retain information". Reid (1995) defined learning styles as "individual's natural, habitual and preferred way(s) of absorbing, processing, and retaining new information and skills". He believes learning styles are internally based characteristics often not perceived or consciously used by learners, for the intake and comprehension of new information. Fleming (2001) defined learning style as "an individual's characteristics and preferred ways of gathering, organizing, and thinking about information. Oxford (2003) defined the term learning style as "the general approach preferred by the student when learning a subject, acquiring a language, or dealing with a difficult problem".

\subsection{Significance and Studies of Learning Styles}

According to Kolb (1984), students appear to learn best when the teaching methods used fit their preferred learning styles. He believes that understanding and addressing learning styles can be a significant help in accomplishing the purpose of education. Brindley (1989) suggests that information has to be exchanged about roles and expectations, both teachers' and learners' awareness of each other's needs and resources has to be raised and compromises have to be reached between what learners expect and want and what the teachers feel they can and should provide. Teachers' awareness of the students' preferred learning styles can help teachers understand and cope with students' course-related learning difficulties and eventually help lessen their frustration levels (Dunn, 1990). Cheminais (2002), Reid (2005) and Burnett (2005) identify learning style as an important idea for inclusive learning and teaching in the classroom. Chang (2003) believes that understanding the students' preferred learning styles has a great impact on curriculum design, teacher training, material development and student orientation.

There have been growing proofs in literature demonstrating that learning style is an important component of language learning procedures. Researches by Kömür (2011), Chermahini, Ghanbari, and Talab ( 2013), Iyer (2015), and Chavosh \& Davoudi (2016) support that learning styles can be considered as a good predictor of any language academic performance, and it should be taken into account to enhance students' performances specifically in learning and teaching language. Therefore, it is significant for teachers to explore and understand their students' learning styles and then make appropriate adjustments in their teaching and techniques to meet students' learning styles and help them in achieving good performance.

\section{Research Methodology}

\subsection{Research Questions}

To be more specific, the present study sought to answer the following questions:

- What are the language learning style preferences of Thai airline business students?

- To what extent, if any, are teachers aware of their students' learning style preferences? 


\subsection{Subjects}

The present study was carried out among 563 students (132 males and 431 females) majoring in airline business at a private university in Thailand. The respondents were first year, second year, and third year students. All of these students were studying English as a foreign language as partial requirement of their Bachelor's degree. The study also incorporated 8 teachers ( 3 males and 5 females) teaching these students in the same institution. The students ranged between 18 - 23 years of age; teachers were between 29 and 43 .

\subsection{Instruments}

A 13-item questionnaire adapted from Brindley (1984) was utilized to collect data for the study. The questionnaire had two versions; Version 1 was designed for students, and Version 2 for teachers. The versions do not differ significantly. Only items 3 and 4 were not included in the teachers' version as they are irrelevant to the teachers.

Each item in the questionnaire explores a particular language learning topic. The questionnaire contains three important sections: Learning, Error Correction and Assessment or Evaluation. Items 1 to 7, 10 and 11 center around the preferred learning styles in acquiring knowledge in language, whereas Items 8 and 9 focus on the learners' preferred methods of correction. The last two items concentrate on learners' preferred methods of assessments. In the learning section, the students were also asked to express their preferences on learning individually, small or big groups apart from the preferred learning modalities; visual, auditory and kinesthetic.

\subsection{Data collection procedures and analysis}

The questionnaires were administered in one single session for the same students. Students were provided the questionnaires during their class periods. Necessary information for completing the questionnaire was provided in Thai to facilitate a better communication. Version 2 of the questionnaires was given to the teachers when they were free in their rooms. There was apparently no time restriction to respond to the items in the questionnaire; however, it was expected that they should finish within 20 (twenty) minutes.

The data collected was analysed using the percentages to achieve the main goal of the study. A t-test was also conducted to observe if there was a correlation between teachers' and students' responses $(\mathrm{p}>0.05)$.

\section{Results and Discussion}

The following are the findings obtained from the analysis of the data. These findings provide some valuable insights into the students' language learning style preferences at the research context and the nature of the course content and classroom activities to be utilized by their teachers;

- Both students and teachers are aware of students' dissatisfaction with their achievement in English. Thus, such findings support the argument that there are needs to examine students' preferences of learning English language and the actual practice.

- Students' tendency toward working in pairs and/or in small groups is well perceived by teachers. But teachers should put less emphasis on the students' working in one large group.

- About half of the students believe that some sort of homework activity will be helpful to their learning and would like to utilize the time preparing for the next class session and reviewing the day's work as well.

- A significant number of students express their views in favor of more outside-classroom activities that will help them gain proficiency in English. The results received by teachers display a significant correlation with those of students.

- A high percentage of students respond in support of "Listening". Likewise, "Repeating what they hear" and "Listening and taking notes" also receive a rather high percentage from students. These preferences are known by their teachers. But teachers should put less emphasis on using the board and forcing students to copy the things on the board. 
- Regarding vocabulary learning, the majority of students give priority to "thinking of relationships between known and new" "saying or writing words several times", and "using new words in a sentence", respectively. Thus, teachers are advised, especially in reading comprehension lessons, to put more emphasis on these and plan some activities to encourage their learning of new words.

- It seems students are not bothered with their teachers' correcting their errors in private or in front of the class. But, they prefer to be corrected later at the end of the activities.

- A significant number of students do not mind having their written work corrected by other students. Teachers also render a correlational response. Regarding correcting their own work, students indicate that they will gladly correct themselves and teachers share this view with their students.

- Regarding the use of media, students would like to see more instructive television programs and video films which make language learning more exciting and meaningful. This is well perceived by their teachers. Thus, teachers are again advised to use more audio-visual materials than the extensive use of the blackboard and tape recorders or audio files.

- The learning activities "talking with and listening to other students" and "learning about culture" seem more appealing to students. Teachers are aware of such preferences. Interestingly, "Role play" and "Songs" do not highly catch the attention of the students. This isn't well perceived by the teachers.

- The majority of the students state that they are satisfied with their achievement in English when they are able to use their language in real life situations, and a significant number of teachers believe that their students usually assess themselves based on their performance in such situations. Teachers can and should indeed occasionally refer to students' opinion about their performance, and ask for recommendations in order to create better learning situations. Such 'non-grading' reference to students' views may yield some outstanding results guiding teachers in many ways: material development, presentation, teacher-student interaction, etc. (Bada \& Okan, 2000).

- Students mostly get a sense of satisfaction not only by getting high grades, but also by seeing that they are more successful than before in using the language to communicate. Teachers share this view with their students.

\section{Conclusion}

For effective language teaching and learning, teachers need to be aware of their students' needs, capabilities, potentials, and learning preferences in meeting these needs. This study dealt with the preferences and the objective behind conducting this study was to come across findings that could feed into classroom practice, and provide guidance for students and teachers as well as material designers and syllabus planners to make appropriate adjustments to meet students' learning styles and help them in achieving good performance. From the study it can be observed that students' preferences do indeed correlate with those of teachers in many cases. However, the results obtained here call for a step forward towards a closer co-operation between teachers and students in some instances in designing syllabuses, doing weekly course planning, and classroom management. Finally, there are scopes of further research, utilizing the results of the present study, whether some other variables like gender, age, educational background, and so on have any effect on the students' specific choice and preference of styles of language learning.

\section{References}

[1] G. P. Brindley, Needs Analysis and Objective Setting in the Adult Migrant Education Program, Sydney, Australia: N.S.W. Adult Migrant Education Service, 1984.

[2] "Test and Score Data Summary for TOEFI iBT Tests," 2015. [Online]. Available: https://www.ets.org/s/toefl/pdf/94227_unlweb.pdf. [Accessed 2 October 2015].

[3] D. Allwright and K. Bailey, Focus on the Language Classroom, Cambridge: Cambridge University Press, 1991.

[4] W. Littlewood, N. Liu and C. Yu, "Hong Kong tertiary students' attitudes and proficiency in spoken English," RELC Journal, vol. 27, no. 1, pp. 70-88, 1996. 
https://doi.org/10.1177/003368829602700104

[5] R. Dunn, "Understanding the Dunn and Dunn learning styles model and the need for individual," Journal of Reading, Writing, and Learning Disabilities International, vol. 6, pp. 223-247, 1990. https://doi.org/10.1080/0748763900060303

[6] G. V. Davidson, "Matching learning styles with teaching styles: Is it a useful concept," Performance \& Instruction, vol. 29, no. 4, pp. 36-38, 1990. https://doi.org/10.1002/pfi.4160290410

[7] T. C. De Bello, "Comparison of Eleven Major Learning Styles Models: Variables, Appropriate Populations, Validity of Instrumentation, and Research behind Them," Journal of Reading, Writing, and Learning Disabilities International, vol. 6, no. 3, pp. 203-222, 1990. https://doi.org/10.1080/0748763900060302

[8] J. Reid, Learning styles in the ESL/EFL classroom, Boston, MA: Heinle and Heinle Publishers, 1995.

[9] N. Fleming, Teaching and learning styles : VARK strategies, Christchurch, N.Z: N.D. Fleming, 2001.

[10] R. L. Oxford, "Language learning styles and strategies: Concepts and relationships," IRAL, vol. 41, no. 4, p. 271-278, 2003. https://doi.org/10.1515/iral.2003.012

[11] D. A. Kolb, Experiential learning: Experience as the source of learning and development, Englewood Cliffs, NJ: Prentice-Hall, 1984.

[12] G. Brindley, "The role of needs analysis in adult ESL program design," in The second language curriculum, Cambridge, Cambridge University Press, 1989, pp. 63-78.

[13] R. Cheminais, Inclusion and School Improvement, London: David Fulton, 2002.

[14] G. Reid, Learning Styles and Inclusion, London: PCP, 2005.

[15] N. Burnett, Leadership and SEN: Meeting the Challenge in Special and Mainstream Settings, London: David Fulton, 2005.

[16] D. Y. Chang, “ English Language Learning Strategies and Style Preferences of Traditional and Nontraditional Students in Taiwan", Unpublished doctoral dissertation. University of South Dakota, 2003.

[17] Ş. Kömür, "The effect of learning style preference on course achievement among preservice English teachers," Problems of Education in the 21 st Century, vol. 29, pp. 71-81, 2011.

[18] S. A. Chermahini, A. Ghanbari and M. G. Talab, "Learning styles and the academic performance of students in English as a second language class in Iran," BJSEP, vol. 7, no. 2, pp. 322-333, 2013.

[19] M. S. Iyer, "ESL Instruction Based on Learning Style for the Faculty of Arts First Year Tamil Medium Undergraduates -University of Jaffna, Sri Lanka," Language in India, vol. 15, no. 1, pp. 306-320, 2015.

[20] M. Chavosh and M. Davoudi, "The Relationship between Perceptual Learning Styles and Reading Comprehension Performance of Iranian EFL Learners," International Journal of English Linguistics, vol. 6, no. 3, pp. 61-69, 2016. https://doi.org/10.5539/ijel.v6n3p61

[21] E. Bada and Z. Okan, "Students' Language Learning Preferences," TESL-EJ, vol. 4, no. 3, pp. A-1, 2000. 